\title{
Effect on Performance and Hematological Profile of Broiler Chicken with Combined Administration of Dietary Ochratoxin and Citrinin
}

\author{
M. Jeevana Latha ${ }^{1 *}$, Ch. Srilatha ${ }^{4}$, Y. Narasimha Reddy ${ }^{2}$ and M.K. Srikanth ${ }^{2}$ \\ ${ }^{1}$ Department of Veterinary Pathology, ${ }^{2}$ Department of Veterinary Microbiology, \\ ${ }^{3}$ Department of Veterinary Pharmacology and Toxicology, College of Veterinary Science, \\ PVNR TVU, Rajendranagar, Hyderabad-30, Telangana, India \\ ${ }^{4}$ Department of Veterinary Pathology, College of Veterinary Science, \\ SVVU, Tirupati, Andhra Pradesh, India \\ *Corresponding author
}

\section{A B S T R A C T}

\section{Keywords}

Broiler chicken, Citrinin, Ochratoxin, Performance and Hematology.

Article Info

Accepted:

19 June 2017

Available Online:

10 August 2017
The present study was conducted to evaluate the effect of combined administration of dietary ochratoxin $(\mathrm{OA})$ and citrinin $(\mathrm{CTN})$ at $2 \mathrm{ppm}$ and $25 \mathrm{ppm}$ respectively on performance traits and haematological profile of broiler chicks for a period of six weeks. Day-old male commercial broiler chicks ( $n=80$; Vencobb strain) were selected to carry out the experimental study. Experimental design consists of four dietary groups which include control (Group -I), toxin (Group-II) and ameliorative groups (Groups III and IV). Clinically toxin group birds were dull and showed watery diarrhoea. Average body weights, feed consumption and feed conversion ratios were calculated at weekly interval of $14^{\text {th }}, 28^{\text {th }}$ and $42^{\text {nd }}$ days of experiment and whole blood samples were collected to estimate haematological profile. The results of the present study revealed a significant $(\mathrm{P}<0.05)$ reduction in the average body weights, Haemoglobin (Hb \%), Packed Cell Volume (PCV \%) and Total Erythrocyte Count (TEC) of the toxin group birds. However, combined toxicity of OA+CTN had no effect of feed consumption and feed conversion ratio.

\section{Introduction}

Ochratoxin and citrinin are nephrotoxic mycotoxins produced by common molds Aspergillus ochraceus and Penicillium viridicatum, which can grow frequently in common feed ingredients of farm animals and poultry (Patil et al., 2014). Besides nephrotoxic effects of OA, it is also hepatotoxic carcinogenic and immunosuppressive in nature, whereas Citrinin is a "Slow-Acting" mycotoxin. OA toxicity is a major problem of worldwide importance in commercial poultry production, resulting in heavy economic losses as it is 2-3 times highly toxic than aflatoxins to the domestic fowl (Zaki et al., 2012). Ochratoxins rather than occurring alone, it is usually associated with various other mycotoxins especially citrinin (Aiko, 2015).

Reports on performance of broiler chicken on combined administration of dietary $\mathrm{OA}+\mathrm{CTN}$ were scanty. Hence, the present study was 
undertaken with an aim of studying performance and hematological changes in broiler chicken under experimental feeding of OA+CTN @ 2ppm and 25ppm respectively in combination and their amelioration with activated charcoal and yeast.

\section{Materials and Methods}

An experiment was carried at Poultry Research Station, C.V.Sc, Hyderabad to study the combined effects of dietary OA, CTN and their amelioration with activated charcoal and yeast.

\section{Experimental birds}

Experiment was carried out for a period of six weeks with a total of 80 day-old commercial male broiler chicks (Vencobb Strain) which were obtained from Venkateshwara Hatcheries, Hyderabad. These chicks were randomly divided into 4 experimental groups and maintained under actual farm conditions.

\section{Experimental feeds}

All the chicks were fed with experimental diets along with their basal diets from 0-3 weeks and finisher diets for 4-6 weeks.

All the four groups were maintained by housing under electrically heated battery brooders with feed and water supplementation ad libitum (Table 1).

\section{Source of toxins}

Ochratoxin was produced by inoculating Aspergillus ochraceus culture, which was obtained from MTCC (Institute of Microbial Technology), Chandigarh, on flake wheat. Citrinin was produced by growing Penicillium citrinum (MTCC-2547) on maize flakes using the method of Nelson et al., (1980).

\section{Source of ameliorative agents}

The physical adsorbent, activated charcoal (Decolorizing Powder) was obtained from "Qualigens fine chemicals, division of GlaxoSmithKline Pharmaceuticals Limited, Mumbai. Likewise the detoxifying agent, lyophilized yeast (Saccharomyces cervisiae) was obtained from APNL Biotechnology Project, Department of Veterinary Biochemistry, C.V.Sc., Rajendranagar.

\section{Experimental design}

Completely Randomized Design.

\section{Performance and haematological studies}

Body weights were recorded at weekly intervals using digital electronic balance and average body weights, feed consumption and feed conversion ratios were calculated replicate wise in all the experimental groups.

Total feed consumed during the week $(\mathrm{g})$ Feed Consumption:

No of birds fed during the week

Total feed consumed / Bird during the week (g)

Feed Conversion Ratio:

Body weight gain /

Bird during the week $(\mathrm{g})$

From the end of $2^{\text {nd }}$ week onwards 6 birds from each group were picked and sacrificed at every fortnight interval $\left(14^{\text {th }}, 28^{\text {th }}\right.$, and $42^{\text {nd }}$ days of experiment) by jugular vein puncture ${ }^{1}$.

Whole blood samples were collected from the sacrificed birds in sterile vials containing Heller and Paul's anticoagulant to analyze haematological parameters. 


\section{Results and Discussion}

\section{Performance and hematology}

\section{Performance traits}

The group II birds showed clinical symptoms like depressed growth, dullness huddling and watery diarrhoea which were moderately ameliorated in groups III \& IV.

\section{Body weights}

Group II birds revealed significant $(\mathrm{P}<0.05)$ reduction in body weights which was in cooccurrence with the findings of earlier reports (Peckham et al., 1971). It was due to susceptibility of young chicken to dietary OA toxicity. Other probable cause might be the effect of toxin on the protein metabolism of birds (Mohiuddin et al., 1993). Comparatively minimum adverse effects were noticed in groups III and IV indicating protection offered by these agents (Table 2 and Fig. 1).

\section{Feed consumption and feed conversion}

There was no significant difference in the feed consumption and feed conversion among the groups I, II, III and IV. However there was an apparent decrease in the mean values of group II when compared to groups I, III and IV (Tables 3 and 4; Figs. 2 and 3).

Table.1 Experimental protocol

\begin{tabular}{|c|c|l|}
\hline Group & Number of Birds & \multicolumn{1}{c|}{ Types of diets } \\
\hline I & 20 & Basal diet \\
II & 20 & Basal diet + Ochratoxin (2ppm) + Citrinin (25ppm) \\
III & 20 & $\begin{array}{l}\text { Basal diet + Ochratoxin (2ppm) + Citrinin (25ppm) + Activated Charcoal } \\
(0.4 \%) \\
\text { Basal diet + Ochratoxin (2ppm) + Citrinin (25pp) + Activated Charcoal } \\
(0.4 \%)+\text { Lyophilized yeast }(0.2 \%)\end{array}$ \\
\hline
\end{tabular}

Table.2 Mean value of weekly body weights (g) as effected by various experimental diets in different group of birds

\begin{tabular}{|l|l|l|l|l|l|l|l|}
\hline Group & I Week & II Week & III Week & IV Week & V Week & VI Week & Mean \pm S.E. \\
\hline Group I & 102.53 & 298.81 & 619.61 & 1064.69 & 1436.42 & 1807.52 & $888.26^{\mathrm{b}} \pm 271.64$ \\
\hline Group II & 111.54 & 317.58 & 550.60 & 984.24 & 1290.84 & 1594.50 & $808.22^{\mathrm{a}} \pm 236.26$ \\
\hline Group III & 110.90 & 311.37 & 610.69 & 1013.92 & 1296.00 & 1694.88 & $839.63^{\mathrm{a}} \pm 247.16$ \\
\hline Group IV & 113.09 & 324.90 & 602.96 & 1008.38 & 1307.42 & 1634.57 & $831.55^{\mathrm{a}} \pm 239.76$ \\
\hline
\end{tabular}

S.E. = Standard Error

Means bearing common superscripts do not differ significantly $(\mathrm{P}<0.05)$.

Table.3 Mean values of weekly feed consumption (g) as effected by various experimental diets in different group of bird

\begin{tabular}{|l|l|l|l|l|l|l|l|}
\hline Group & I Week & II Week & III Week & IV Week & V Week & VI Week & Mean \pm S.E. \\
\hline Group I & 92.93 & 259.18 & 453.38 & 497.96 & 508.10 & 723.63 & $422.53 \pm 89.43$ \\
\hline Group II & 96.61 & 265.61 & 460.66 & 479.68 & 458.47 & 697.88 & $409.81 \pm 84.01$ \\
\hline Group III & 96.68 & 257.12 & 445.15 & 506.84 & 525.52 & 706.64 & $422.99 \pm 88.03$ \\
\hline Group IV & 96.25 & 264.81 & 423.00 & 544.11 & 542.89 & 703.47 & $429.08 \pm 89.31$ \\
\hline
\end{tabular}

S.E. $=$ Standard Error 
Table.4 Mean values of weekly feed conversion ratio (g) as effected by various experimental Diets in different group of birds

\begin{tabular}{|l|l|l|l|l|l|l|l|}
\hline Group & I Week & II Week & III Week & IV Week & V Week & VI Week & Mean \pm S.E. \\
\hline Group I & 1.63 & 1.32 & 1.41 & 1.11 & 1.36 & 1.94 & $1.46 \pm 0.12$ \\
\hline Group II & 1.45 & 1.28 & 1.97 & 1.10 & 1.49 & 2.29 & $1.59 \pm 0.18$ \\
\hline Group III & 1.45 & 1.28 & 1.48 & 1.25 & 1.86 & 1.77 & $1.52 \pm 0.10$ \\
\hline Group IV & 1.40 & 1.25 & 1.52 & 1.34 & 1.81 & 2.16 & $1.58 \pm 0.14$ \\
\hline
\end{tabular}

S.E. $=$ Standard Error

Table.5 Mean values of Hemoglobin ( $\mathrm{g} \%$ ) as effected by various experimental diets in Different group of birds

\begin{tabular}{|l|l|l|l|l|}
\hline \multirow{2}{*}{ Groups } & \multicolumn{3}{|c|}{ Age in days } & \multirow{2}{*}{ Mean \pm S.E. } \\
\cline { 2 - 4 } & \multicolumn{1}{|c|}{$\mathbf{1 4}$ days } & \multicolumn{1}{|c|}{$\mathbf{2 8}$ days } & 12.40 & \\
\hline Group I & 12.00 & 11.20 & 6.60 & $11.87^{\mathrm{b}} \pm 0.35$ \\
\hline Group II & 7.40 & 9.80 & 8.20 & $7.93^{\mathrm{a}} \pm 0.96$ \\
\hline Group III & 6.00 & 9.80 & 11.00 & $8.00^{\mathrm{a}} \pm 0.96$ \\
\hline Group IV & 7.60 & 9.80 & $9.47^{\mathrm{a}} \pm 1.00$ \\
\hline
\end{tabular}

S.E. $=$ Standard Error

Means bearing common superscripts do not differ significantly $(\mathrm{P}<0.05)$.

Table.6 Mean values of PCV (\%) as effected by various experimental diets in Different group of birds

\begin{tabular}{|l|l|l|l|l|}
\hline \multirow{2}{*}{ Groups } & \multicolumn{3}{|c|}{ Age in days } & \multirow{2}{*}{ Mean \pm S.E. } \\
\cline { 2 - 4 } & \multicolumn{1}{|c|}{$\mathbf{1 4}$ days } & \multicolumn{1}{|c|}{$\mathbf{2 8}$ days } & 26.00 & \\
\hline Group I & 26.00 & 27.00 & 23.00 & $26.33^{\mathrm{b}} \pm 0.33$ \\
\hline Group II & 23.00 & 22.00 & 27.00 & $22.67^{\mathrm{a}} \pm 0.33$ \\
\hline Group III & 26.00 & 26.00 & 26.00 & $26.33^{\mathrm{a}} \pm 0.33$ \\
\hline Group IV & 24.00 & 25.00 & $25.00^{\mathrm{a}} \pm 1.58$ \\
\hline
\end{tabular}

S.E. $=$ Standard Error

Means bearing common superscripts do not differ significantly $(\mathrm{P}<0.05)$.

Table.7 Mean values of TEC (millions /cu.mm) as effected by various experimental diets in Different group of birds

\begin{tabular}{|l|l|l|l|l|}
\hline \multirow{2}{*}{ Groups } & \multicolumn{2}{c|}{ Age in days } & \multirow{2}{*}{ Mean \pm S.E. } \\
\cline { 2 - 4 } & \multicolumn{1}{c|}{ 14 days } & \multicolumn{2}{c|}{$\mathbf{2 8}$ days } & \multicolumn{2}{c|}{ days } & \\
\hline Group I & 2.88 & 2.15 & 2.72 & $2.58^{\mathrm{b}} \pm 0.22$ \\
\hline Group II & 1.82 & 1.87 & 1.82 & $1.84^{\mathrm{a}} \pm 0.02$ \\
\hline Group III & 1.79 & 1.96 & 2.70 & $2.15^{\mathrm{a}} \pm 0.28$ \\
\hline Group IV & 2.13 & 1.93 & 2.95 & $2.34^{\mathrm{a}} \pm 0.31$ \\
\hline
\end{tabular}

S.E. $=$ Standard Error

Means bearing common superscripts do not differ significantly $(\mathrm{P}<0.05)$. 
Fig.1 Mean value of weekly body weights (g) as effected by various experimental diets in different group of birds

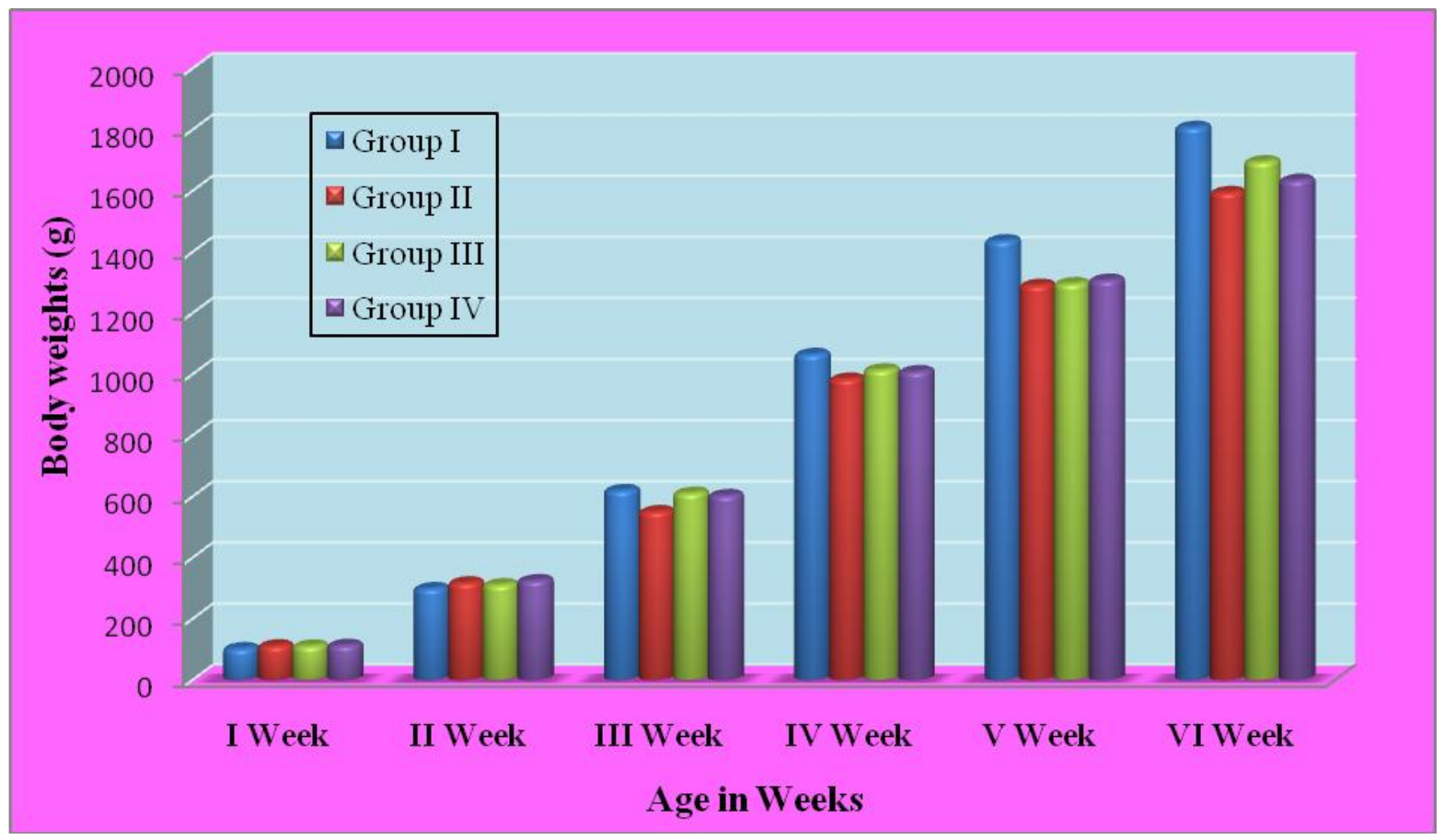

Fig.2 Mean values of weekly feed consumption $(\mathrm{g})$ as effected by various experimental diets in different group of bird

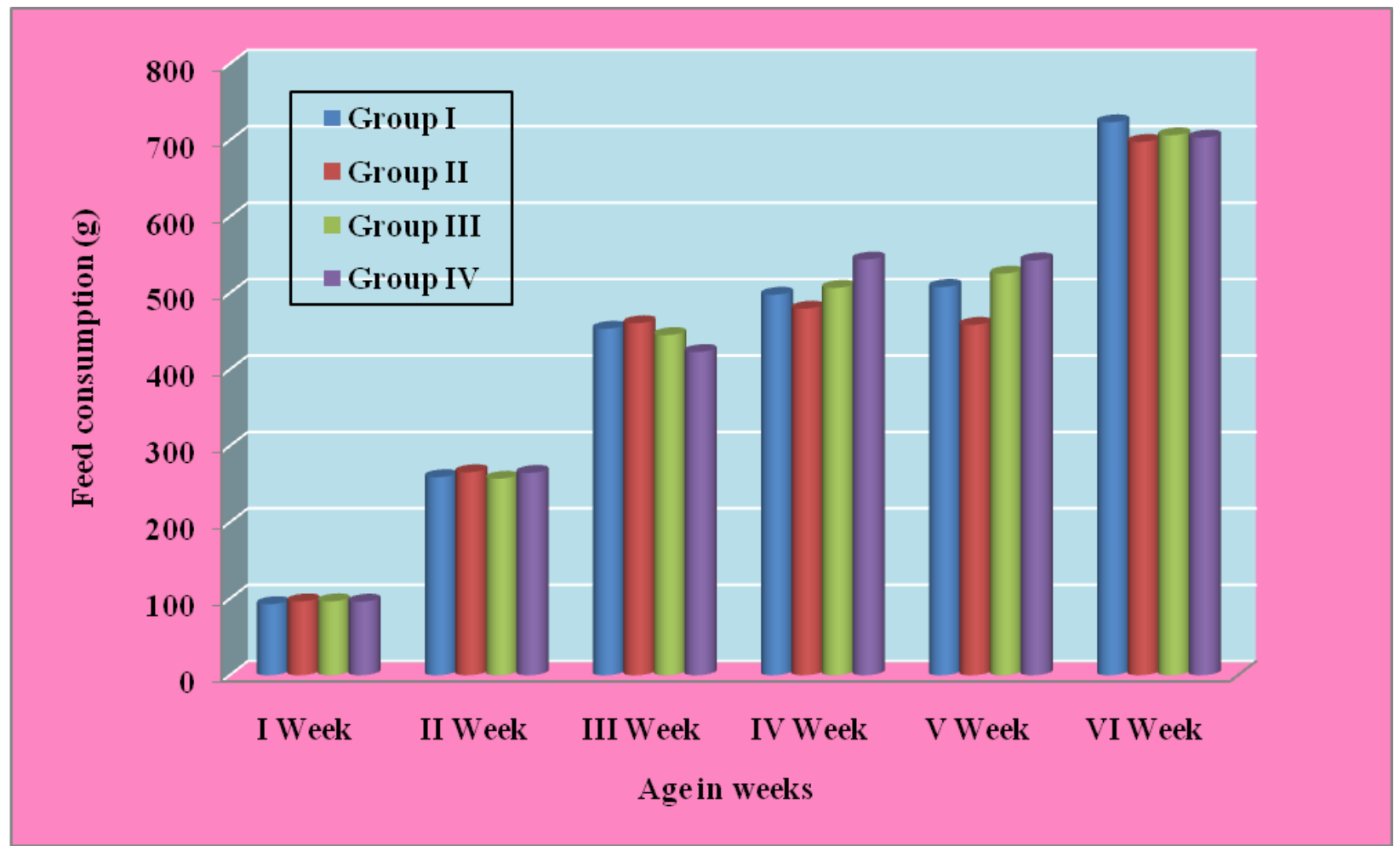


Fig.3 Mean values of weekly feed conversion ratio $(\mathrm{g})$ as effected by various experimental diets in different group of birds

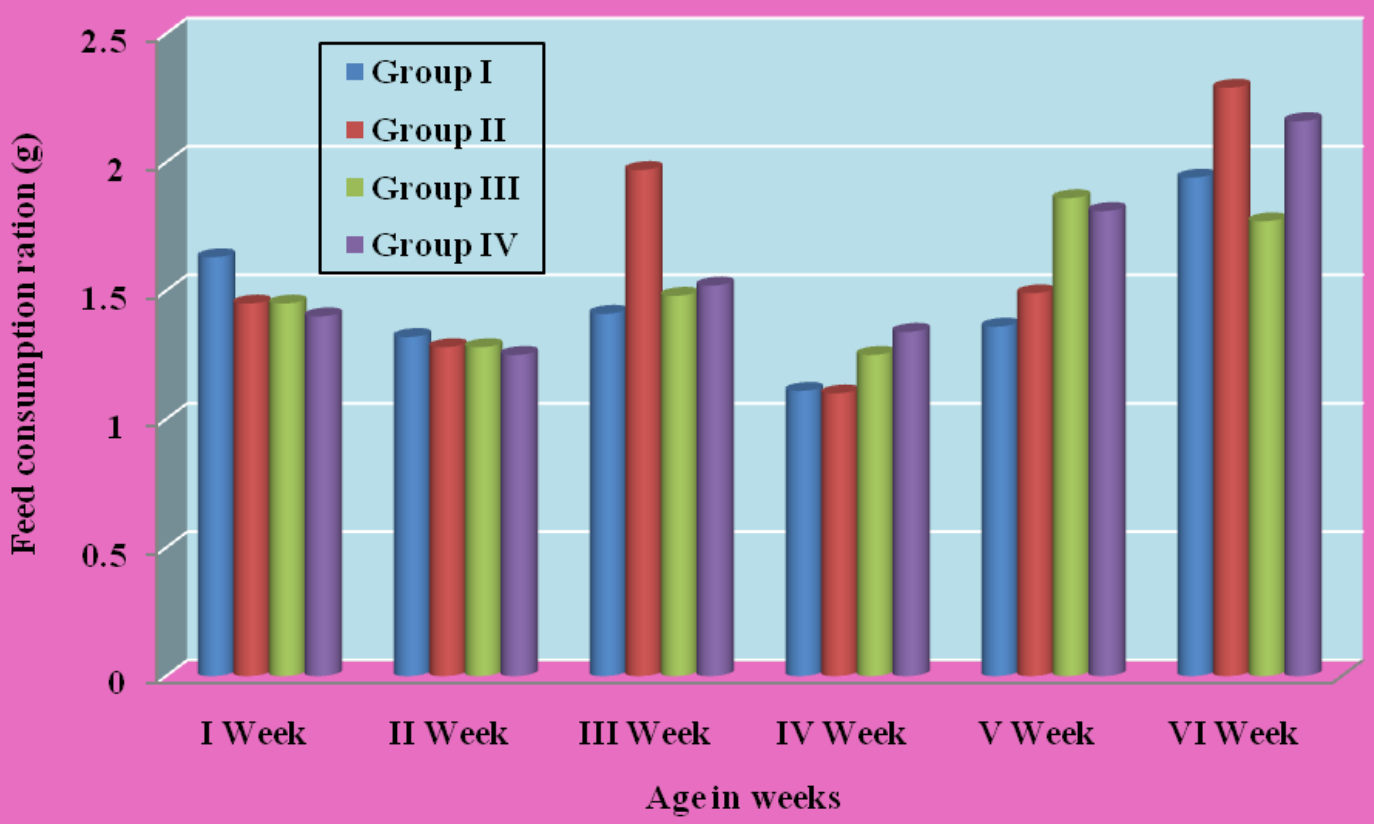

Fig.4 Mean values of Haemoglobin (g \%) as effected by various experimental diets in different group of birds

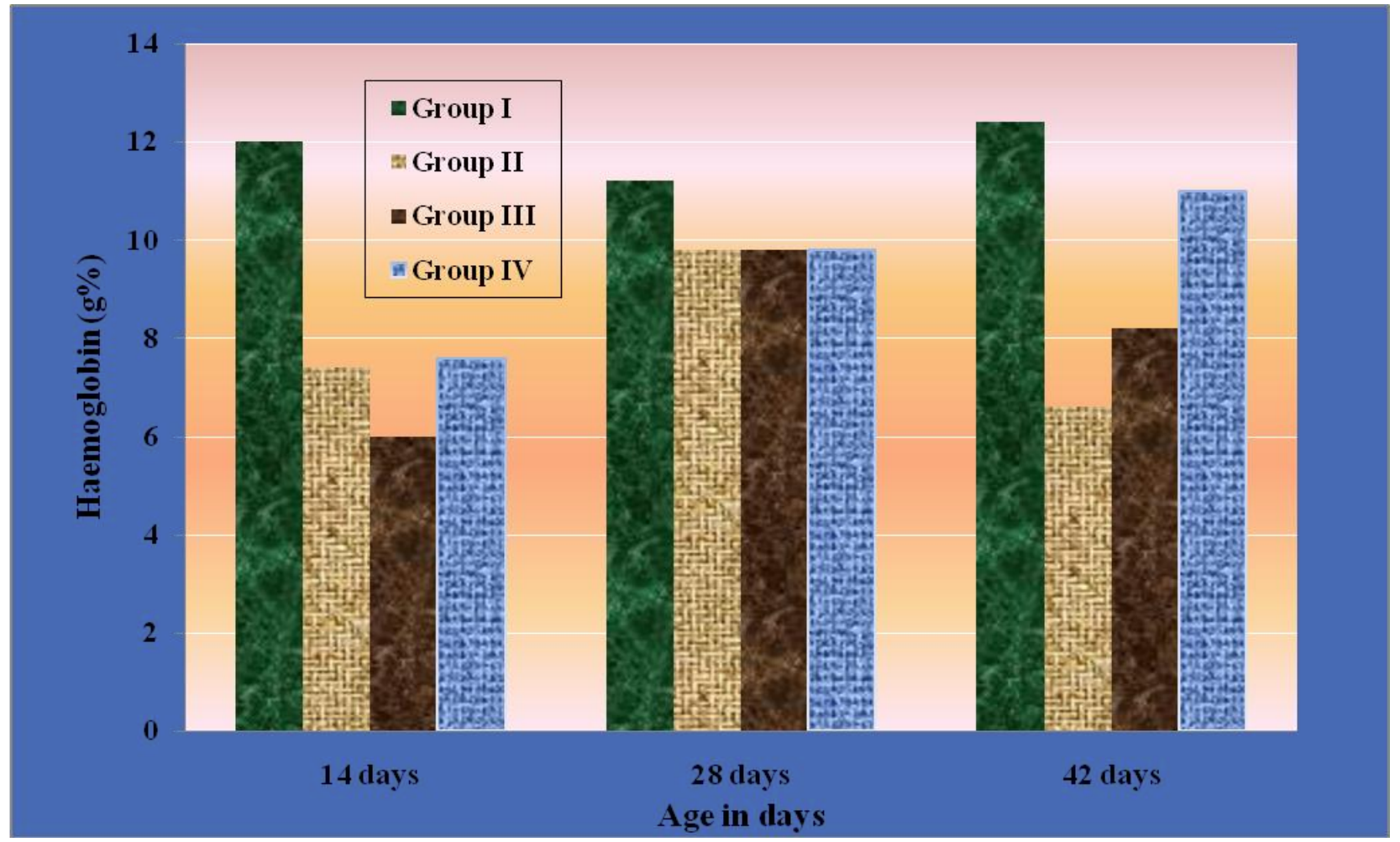


Fig.5 Mean values of PCV (\%) as effected by various experimental diets in different group of birds

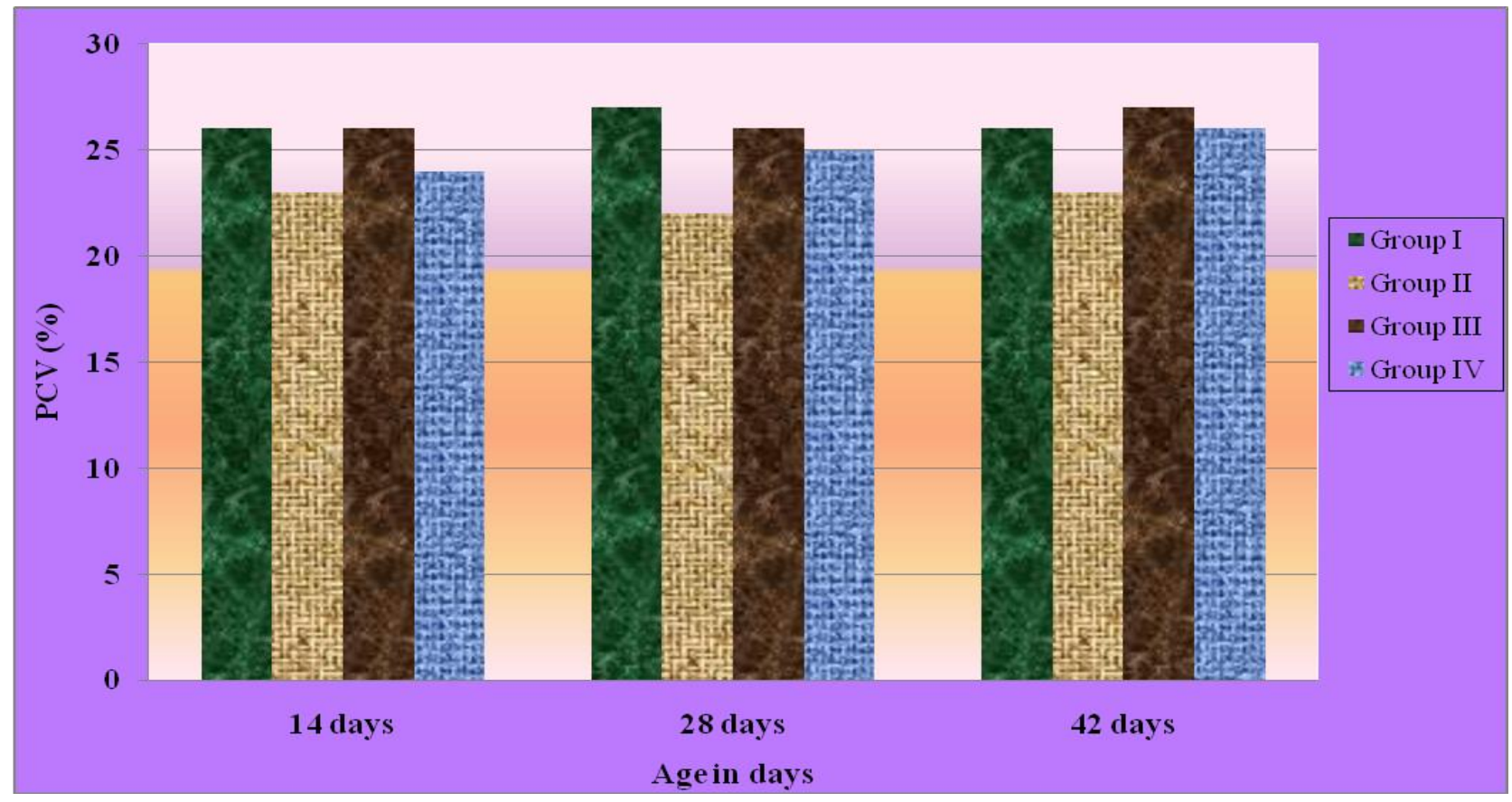

Fig.6 Mean values of TEC (millions /cu.mm) as effected by various experimental diets in different group of birds

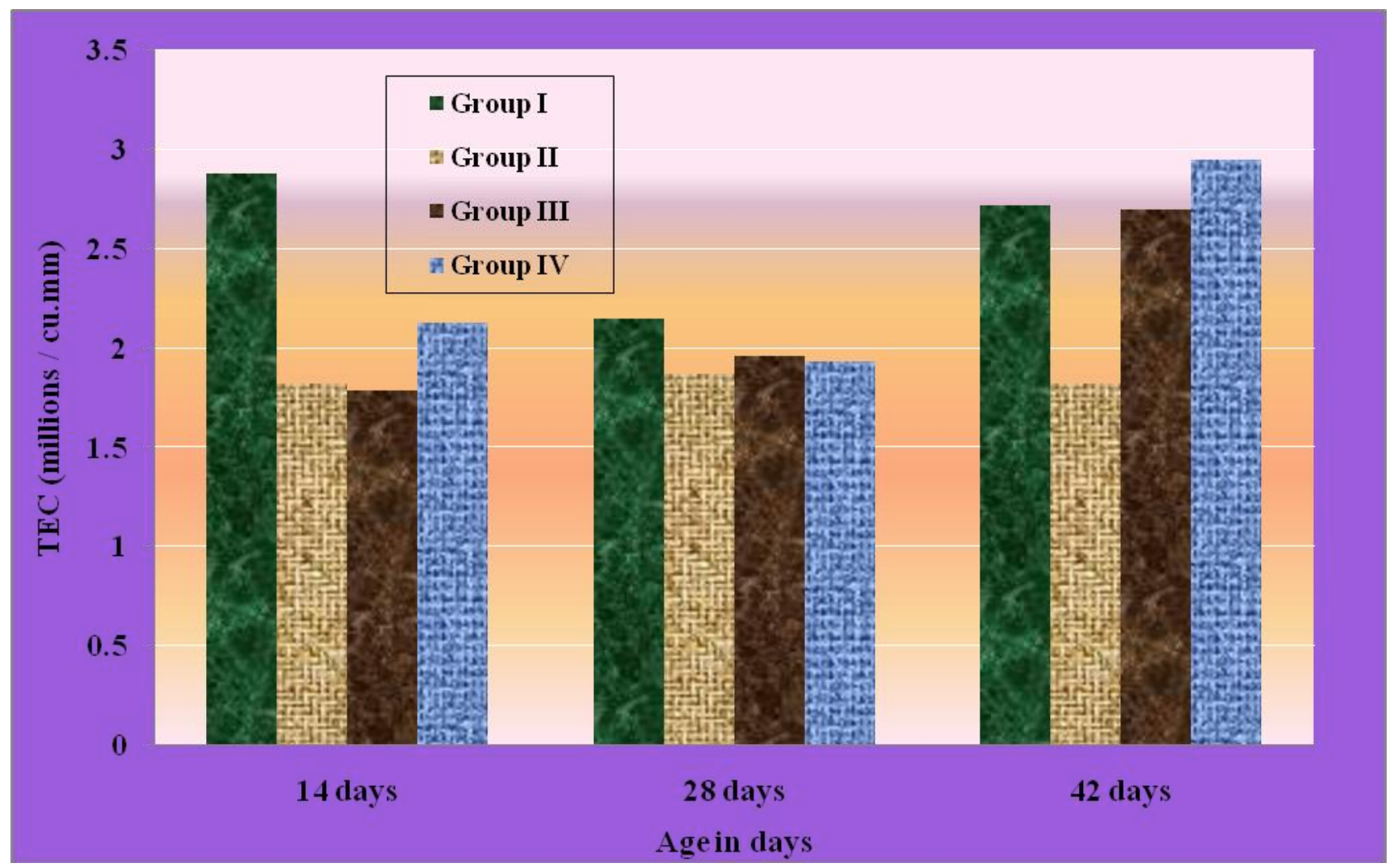




\section{Hematology}

$\mathrm{HB} \%$, PCV\% and TRBC counts were significantly $(\mathrm{P}<0.05)$ decreased in toxin group when compared to control group. The results of the present study were in agreement with several reports (Mohiuddin et al., 1992). The depression in the hematological profile might be due to suppression of hematopoiesis (Nelson et al., 1980). Another simplest explanation for "Iron deficiency anemia" induced by $\mathrm{OA}$ is inhibition of iron absorption from the gastrointestinal tract ${ }^{3}$ (Tables 4,5 and 6 and Fig. 3, 4 and 5).

The results of the present study suggested that feeding of $\mathrm{OA}+\mathrm{CTN} \quad(2 \mathrm{ppm}+25 \mathrm{ppm})$ experimental diets to the broiler chicken for a period of 6 weeks produced a significant $(\mathrm{P}<0.05)$ reduction in average body weights, $\mathrm{Hb} \%$, PCV and TEC (Table 7 and Fig. 6) counts indicating the severity of OA+CTN combined toxicity in altering the physiological regulatory mechanisms of birds.

\section{References}

Aiko, V and Mehta, A. 2015. Occurrence, detection and detoxification of mycotoxins. J. Biosci., 40(5) 943-954.

Mohiuddin, S.M., Reddy, M.V and Ahmed, S.R. 1992. Studies on Ochratoxicosis in broiler chicks. Indian Vet. J., 69:1011-1014.

Mohiuddin, S.M., Warasi, S.M.A and Vikram Reddy. 1993. Haematological and Biochemical changes in experimental Ochratoxicosis in broiler chicken. Indian Vet. J., 70 July: 613-617.

Nelson, T.S., Beasley, J.N and Kirby, L.K. 1980. Citrinin toxicity in chicks. Poult. Sci., 59 (7): 1643-1644.

Patil, R.D., Sharma, R. and Asrani, R.K., 2014. Mycotoxicosis and its control in poultry: A review. Journal of Poultry Science and Technology, 2(1), pp.110.

Peckham, J.C., Doupnik, B and Jones, O.H. 1971. Acute toxicity of ochratoxins A and B in chicks. Appl. Microbiall., 37:601-604.

Schatzmyr, G., Heidler, D., Fuchs, E., Nitsch, S., Mohni, M., Taubel, M., Loibner, A.P., Braun, R. and Binder, E.M. 2003. Investigation of different yeast strains for the detoxification of Ochratoxin A. Mycotoxin Res., 19(2):124-128.

Zaki, M.M., El-Midnay, S.A., Shaheen, H.M and Rizzi, L. 2012. Mycotoxins in animals: Occurrence, effects, prevention and management. $J$. Toxicol. Environ. Health Sci., 4(1): 13-28.

\section{How to cite this article:}

Jeevana Latha, M., Ch. Srilatha, Y. Narasimha Reddy and Srikanth, M.K. 2017. Effect on Performance and Hematological Profile of Broiler Chicken with Combined Administration of Dietary Ochratoxin and Citrinin. Int.J.Curr.Microbiol.App.Sci. 6(8): 1880-1887. doi: https://doi.org/10.20546/ijcmas.2017.608.222 